\title{
DMFT in Iranian 12-year-old students residing in the desert region and its association with their individual and family factors- 2016
}

\section{Ali Alami}

Gonabad University of Medical Sciences

saeed erfanpoor ( $\nabla$ saeed.erfanpoor@yahoo.com )

Iran University of Medical Sciences https://orcid.org/0000-0002-2633-8953

\section{Ali Ramezani}

Gonabad University of Medical Sciences

Alireza Jafari

Gonabad University of Medical Sciences

\section{Research}

Keywords: DMFT, students, Iran

Posted Date: January 17th, 2020

DOI: https://doi.org/10.21203/rs.2.21196/v1

License: (c) (i) This work is licensed under a Creative Commons Attribution 4.0 International License. Read Full License 


\section{Abstract}

\section{Background}

Oral health in students, as an important health-related subject, would be effective on their growth, selfconfidence, socialization, learning ability, daily activities, and quality of life. The aim of this study was to evaluate the DMFT index of 12-year-old students in Gonabad and Bajistan and its relation with their personal and family factors.

\section{Methods}

An analytic-cross sectional study conducted among 1280 the students residing in the two desert districts of Iran in 2016. The required data including the subjects' demographic and family factors as well as their oral health situation extracted from The National School Oral Health Program. The data entered in SPSS (20) and analyzed via Kruskal Wallis, Mann-Whitney, and logistic regression model.

\section{Results}

Mean (SD) of the students' DMFT was 1.47 (1.82). This index was calculated 0.98 (1.47) for boy students and 1.91 (1.98) for girl students $(P<0.001)$. There were significant association between mean of the students' DMFT and their residency location $(P=0.015)$, birth rank $(P=0.032)$, and level of education of their mothers $(P=0.035)$.

Conclusion

According to the findings, attention to oral health in students, especially in girls, seems necessary. Increasing the knowledge and sensitivity of parents (especially mothers) concerning oral health of their children, especially their girls, the use of intermediate forces such healthcare providers in school and oral health technicians in health centers, and the implementation of preventive interventions such as fissure sealant, fluoride varnish Therapy, and use of sodium fluoride mouthwash by students would be effective for improving the oral health of students.

\section{Background}

Oral Health is an important and necessitate part of public health which affects individuals' quality of life. This is more important in children, because it leads to various complications such as dental pain, problems in speaking, general disorders, and psychological problems. It influences on their growth, weight, self-confidence, socialization, daily activity, and ability to learning $(1-3)$. The World Health Organization (WHO) has also identified dental caries as a health problem with a prevalence of 60 to 90 percent among children (4). The high prevalence of dental caries has not only negative effects on quality of life of children and their parents (5), but also imposes heavy costs on health systems in countries (6). Although the oral health situation has recently improved in the world, dental caries is still one of the most important public health problems even in industrialized countries where preventive programs are not well 
established or well implemented $(7,8)$. In US, for instance, prevalence of dental caries is five times higher than asthma and seven times higher than seasonal allergies (9). One of the important age groups for evaluating the oral health, which is also affirmed by the WHO, is the age group of 12; because in most countries nearly all the 12-year children are in school, and most of their permanent teeth are likely to develop (10).

The most important indicator used to assess oral health status is DMFT (permanent Decay, Missing, Filling Tooth) (11). According to studies conducted in Iran, the DMFT in all Iranian children and in 12-year children was 2.30 and 1.84, respectively $(8,12)$, which is still far from the WHO target for 2015 (DMFT 1 or below) (13).

Various studies have found that many factors such as Socio-Economic Status (SES), parents' education level and occupation, sex, and birth rank would affect the children's oral health status $(9,14)$. There are also some studies that, in desert areas, show the DMFT among children is roughly high (15-19); Therefore, since Iran is still considered as a young country (20), planning and implementing to prevent and treat oral diseases would be necessary.

The first step seems to be the implementation of studies and the comprehensive evaluations of oral health indicators and the factors affecting it on a national and regional level, which can play an important role both to design of interventions and to prevent and treat illnesses associated with oral and dental problems $(7,21)$. Meanwhile, Gonabad and Bajestan are two desert cities locating in Eastern part of Iran. The results of some studies in similar climate zones in Iran show a high DMFT index in these areas (15), although other studies in tropical and desert regions have reported different results $(22,23)$. So, according to the above mentioned issues as well as the importance of regional studies to recognize the oral health status and, if necessary, design and implement intervention programs appropriate to the regional conditions, this study aims to examine the DMFT in 12-year-old students of Gonabad and Bajestan and determine some of their affecting factors.

\section{Methods}

This analytic, cross-sectional study was conducted among 1280 the 12-year-old students in Gonabad and Bajestan in 2016. The required data were collected from the National Oral Health Program of Students which was implemented by Deputy for Health of Gonabad University of Medical Sciences and was supervised by the Iran's Ministry of Health and Medical Education. In this national plan, all elementary students were examined by dentists working in the health centers and their data were entered into a checklist. The checklist includes data about the student's characteristics (name, sex, date of birth, birth rank, and father's name), his/her family-social characteristics (place of residence, parent's age, job, and level of education, birth rank, number of siblings), and oral health condition of the respondents (using toothbrush, dental floss, and sodium fluoride mouthwash). In this study, the diagnosis of dental caries was performed by the dentists using a catheter and a mirror of the dental bed and natural light by observation and then touching the catheter. The data obtained from the examination were then recorded 
in the checklist for each student. The collected data were entered into SPSS (Version 20(. Comparing the groups, we used Mann-Whitney and Kruskal-Wallis tests. Univariate and multiple logistic regression model was used to determine the simultaneous effects of the variables on DMFT. In all the tests, a significant level of 0.05 was considered.

\section{Results}

In this study, data from the 1280 subjects (601 boys and 679 girls) were analyzed. The mean (SD) of total DMFT was 1.47 (1.82). Table 1 shows the respondents' DMFT and its relation with their personal, family and dental health behaviors.

Data analysis results using the logistic regression model are presented in Table 2. First, the variables were introduced into the univariate model. Each of them which had P-Value $<0.2$ entered the multivariate model. This is a known method which was suggested by Jewell (Jewell NP. Statistics for epidemiology. California, Chapman \& Hall/CRC, 2004) and applied in some studies (24).

\section{Discussion}

This study conducted to determine the status of DMFT among 12-year-old students in Gonabad and Bajnestan, two desert districts and its association with their individual and family characteristics in 2016. The total mean (SD) of the students' DMFT was $1.47 \pm 1.82$ (in boys and girls $0.98 \pm 1.47$ and $1.91 \pm 1.98$, respectively). Also, based on the results of multiple logistic regression analysis, DMFT index had a significant relationship with the subjects' sex, parents' education, birth rank, and place of residence, but not with dental health behaviors of the students.

In our study, the students' DMFT was 1.47 which was less than in Iran, as a whole (1.84) as well as in Khorasan Razavi province (1.71), based on the latest national oral and dental health survey (10). This was also less than some similar studies in Iran $(25,26)$, Saudi Arabia (27), Eritrea (23), Korea (28), and Libya (29); while more than that of some studies in India, China and Sudan $(7,22,30)$. This discrepancies in various studies conducted in different geographical areas with different climate situations indicate that oral and dental health, rather than being affected by climate condition, are more affected by factors such as cultural, racial, access to dental services, nutritional habits, lifestyle, and the students' status of education for dental health and providing preventive dental health services to them $(23,31,32)$.

There was statistically significant difference between DMFT of the girls and boys in our study; so that the odds of caries in the girls was 2.69 times of the boys. This was consistent with the results of Zhang et al. (33) and Huew et al. (29) Yousefi et al. (34) and Gorgi et al. (14); but not to the results of study by AlAkwa et al. (3) and Andegiorgish et al (23) and Toomarian et al (35). The high DMFT index in girls may be due to the earlier onset of permanent teeth, which makes their teeth longer exposed to rot; though, this measure, probably in the long run, become equivalent in both sexes $(23,27)$. 
The results of this study showed that there is a significant association between the students' DMFT and their residency location which means the students living in urban areas had higher odds of caries than those in rural areas $(O R=1.48)$. This is comparable with the results of $d$ Al-Akwa et al. studies $(3)$, while our result is not similar to Giacaman et al (36) study results. One of the potential explanation for this difference is that the urban students have probably more access to sugary foods and beverages, snacks (i.e. puff and chips), and fast food than rural students (3). These edibles could increase the risk of dental caries. Differences in Fluoride drinking water between urban and rural areas could be another reason for this discrepancy. Besides, because of lower student population in rural areas, better implementation of and more success in dental health programs such as using sodium fluoride mouthwash by students, varnish Fluoride therapy and fissure Sealant for Students would be a potential outcome. Although more studies need to evaluate this probability.

Our results showed that there is a significant relationship between the students' DMFT and their mother level of education, which means that with the increase of mothers' education, the chance of dental caries in students is higher. Although the results of many studies in many countries such as Iran (37-39), China (40), and Greece (41) are not similar to our findings, some studies have not reported a meaningful statistical relationship between parents' education and dental caries. Of their children $(42,43)$. Even a Norwegian study showed that the chances of dental decay in children with one or both parents with low level of education are two and three times higher than children who have parents with high education level, respectively (44). Possible reasons for the difference in outcome may be due to differences in the age of the subjects, consideration of the parents' employment status, cultural and socioeconomic status of the children, and statistical methods used in various studies.

In our study, there was a direct association between the subjects' DMFT and their birth rank. Indeed, the odds of dental caries of the students increased with their birth ranks. This was comparable with other studies $(45,46)$. This result is due to the fact that the increase in the number of children in the family is likely to reduce the parental attention of children. In addition, the number of children increase, the household expense increase; therefore, the possibility of receiving dental health care for children decrease and, subsequently, the probability of their dental caries increase (46).

In our study, there was no significant association between the students' DMFT and their oral hygiene behavior such as using dental floss and brushing. Besides, there was no meaningful relationship between DMFT and using sodium fluoride mouthwash by the students. Our findings are similar to the results of QUAN and colleagues (40) in China, but inconsistent with Al-Akwa et al study results (3). It seems quality of dental floss use and brushing plays an important role in the prevention of dental caries. Meanwhile, the results of various studies have shown that the presence of standard fluoride in drinking water (3), as well as in mouthwashes and toothpastes, would be one of the effective factors on reducing dental decay (47). Therefore, since the fluoride is not added to drinking water in Iran, use of sodium fluoride mouthwash and fluoride-containing toothpastes, if used correctly and adequately, is recommended as routine intervention to reduce tooth decay. 
There are some strengths in our study. Determining the oral health status by the dentist, using country program data, and entering the entire target population are some of the strengths of the study. One of the potential limitations is the use of more than one dentist in the Oral Health Program of Gonabad and Bajestan Students. This may have led to an inaccuracy of the gathered data due to inter-personal variation. To control this concern, all dentists were initially trained on how to implement the national plan, and they used the same checklist during the implementation of the plan. Moreover, the required data were extracted from the checklists used in the national program for oral health; so, the probability of inaccuracy in completing them would be another limitation of the present study.

\section{Conclusion}

The results of the current study showed an association between DMFT of the 12-year-old students and their sex, birth rate, parents' education and place of residence. Although the DMFT in Gonabad and bajestan, in comparison with national target, would be acceptable, this is far from the goal announced by WHO for 2015 (DMFT one or below). To meet the goal, it seems applying qualified and timely preventive dental health interventions including students' mouthwash program, fissure sealant, and varnish fluoride therapy would probably be helpful. Improving the level of people's health literacy through mass media and strengthening the performance of school health educators to sensitize the students and their parents to use the above preventive programs could also be considered as other effective methods for promoting student's oral health.

\section{Abbreviations}

DMFT: Decayed, Missing, and Filled Teeth; WHO: World Health Organization; SD: Standard Deviation;

\section{Declarations}

\section{Acknowledgment}

This study sponsored by Social Determinants of Health (SDH) Research Center, and vice chancellery for research and technology of Gonabad University of Medical Sciences. We are grateful for the co-operation of all university staff, education staff, students, and the efforts of colleagues at the Social determinants of Health Research Center that assisted us in this project.

\section{Author Contributions Statement}

Contributions: research idea and study design: S.E., A.A, A.J, A.R, statistical analysis and write the first draft of the manuscript: S.E., A.A, A.J, helped as a consultant on the study design: A.R, S.E, A.A, critically and substantially revised the final article: S.E., A.A, A.J, A.R. All authors read and approved the final manuscript

\section{Authors' information}


${ }^{1} \mathrm{MD}, \mathrm{PhD}$ in Epidemiology. Department of Epidemiology and Biostatistics, School of Public Health; Social Determinants of Health Research Center, Gonabad University of Medical Sciences, Gonabad, Iran, ${ }^{2} \mathrm{PhD}$ student of epidemiology, Department of Epidemiology, Iran University of Medical Sciences, Tehran, Iran,

${ }^{3}$ Dentists. Deputy for Health, Gonabad University of Medical Sciences, Gonabad, Iran, ${ }^{4} \mathrm{PhD}$ student of Health Education and Health Promotion. Social Determinants of Health Research Center, Gonabad University of Medical Sciences, Gonabad, Iran.

\section{Funding/Support:}

This study is funded by a research grant from the Gonabad University of Medical Sciences. The funding body (GUMS) didn't have any role in the design of the study and collection, analysis, and interpretation of data and in writing the manuscript

\section{Availability of data and materials}

Data is available by the corresponding author on reasonable request.

\section{Ethics approval and consent to participate}

Ethical approval was received for this study from the Ethics Committee of The Gonabad University of Medicine Sciences (IR.GMU.REC.1394.100).Written informed consent was obtained from parent/guardian of students participated in this study.

\section{Consent for publication}

Not applicable.

\section{Competing Interests:}

The authors declare no conflict of interest

\section{References}

1. Dukic W, Delija B, Lulic Dukic O. Caries prevalence among schoolchildren in Zagreb, Croatia. Croatian medical journal. 2011;52(6):665-71.

2. Tafere Y, Chanie S, Dessie T, Gedamu H. Assessment of prevalence of dental caries and the associated factors among patients attending dental clinic in Debre Tabor general hospital: a hospital-based cross-sectional study. BMC oral health. 2018;18(1):119-.

3. Al-Akwa AA, Al-Maweri SA. Dental caries prevalence and its association with fluoride level in drinking water in Sana'a, Yemen. European journal of dentistry. 2018;12(1):15.

4. World Health Organization. Oral Health fact sheet April 2012. [cited Jan 2019]. Available from: https://www.mah.se/CAPP/Oral-Health-Promotion/WHO-Oral-Health-Fact-Sheet1/. 
5. Kumar S, Kumar A, Badiyani B, Kumar A, Basak D, Ismail MB. Oral health impact, dental caries experience, and associated factors in 12-15-year-old school children in India. International journal of adolescent medicine and health. 2017;29(2).

6. Listl S, Galloway J, Mossey PA, Marcenes W. Global Economic Impact of Dental Diseases. Journal of dental research. 2015;94(10):1355-61.

7. Mittal M, Chaudhary P, Chopra R, Khattar V. Oral health status of 5 years and 12 years old school going children in rural Gurgaon, India: An epidemiological study. Journal of Indian Society of Pedodontics and Preventive Dentistry. 2014;32(1):3-8.

8. Pournaghi-Azar F, Asl-Aminabadi N, Jamali Z, Azami A, Hazem K, Azami-Aghdash S, et al. Status of decayed, missing, filled teeth index among Iranian children and adults: A systematic review and meta-analysis. Journal of Analytical Research in Clinical Medicine. 2018;6(2):55-66.

9. Al-Darwish M, El Ansari W, Bener A. Prevalence of dental caries among 12-14year old children in Qatar. The Saudi Dental Journal. 2014;26(3):115-25.

10. World Health Organization Oral health surveys: basic methods - 5th edition [cited Aug 2018]. Available from: http://www.who.int/oral_health/publications/9789241548649/en/.

11. Khamis AH. Re-Visiting the Decay, Missing, Filled Teeth (DMFT) Index with a Mathematical Modeling Concept. Open Journal of Epidemiology. 2015;6(01):16.

12. Oral Health Office of the Ministry of Health of the Islamic Republic of Iran.[homepage on the Internet]. [cited Aug 2018]. Available from: http://iranoralhealth.ir/wpcontent/uploads/2017/11/\%D9\%86\%D8\%AA\%D8\%A7\%DB\%8C\%D8\%AC\%D9\%BE\%DB\%8C\%D9\%85\%D8\%A7\%DB\%8C\%D8\%B4.pdf.

13. Petersen PE. The World Oral Health Report 2003: continuous improvement of oral health in the 21st century-the approach of the WHO Global Oral Health Programme. Community Dent Oral Epidemiol. 2003;31 Suppl 1:3-23.

14. Gorgi Z, Abbasi A, Mohsenzadeh A, Damankeshan A, Sheikh Fathollahi M. A survey on DMFT index of the first permanent molar in 12-year-old students of Larestan, Iran, in 2014. Journal of Occupational Health and Epidemiology. 2017;6(1):32-9.

15. Amirabadi F, Rahimian-Imam S, Ramazani N, Saravani S, Kameli S. Evaluation of Dental Status and Its Association with Oral Health-Related Quality of Life in Preschool Children in Zahedan City, Iran: A Cross-Sectional Study. Middle East J Rehabil Health. 2017;4(1):e37043.

16. Yun S, Shin S, Chang Y, Kim H, Sohn S, Kim J, et al. A survey of dental caries in Mongolia in 2014. Int J Clin Prev Dent. 2014;10:165-78.

17. Khazaei M, Mahvi AH, Fard RF, Izanloo H, Yavari Z, Tashayoei HR. Dental caries prevalence among Schoolchildren in Urban and Rural areas of Qom Province, Central part of Iran. Middle-East J Sci Res. 2013;18(5):584-91.

18. Modasiya V, Bohra D, Bahura C. Implication of fluoride toxicity on human health in a village of Indian Thar Desert, Rajasthan, India. Asian J Biochemic Pharmac Res. 2014;4(4):52-9. 
19. Chatterjee M, Bandyopadhyay AR. A study on nutritional status and dental caries in permanent teeth among school going girl of Bengalee Population, India. Advances in Anthropology. 2012;2(03):112.

20. Gh.Jalil Seminar Report Pakistan-China-Iran: A Trident of Regional Connectivity December 19, 2017. [cited 2019 AUG 27]. Available from: http://issi.org.pk/wpcontent/uploads/2018/03/Seminar_Report_Dec_19_2018.pdf.

21. Fernandez MR, Goettems ML, Ardenghi TM, Demarco FF, Correa MB. The Role of School Social Environment on Dental Caries Experience in 8- to 12-Year-Old Brazilian Children: A Multilevel Analysis. Caries Res. 2015;49(5):548-56.

22. Nurelhuda NM, Trovik TA, Ali RW, Ahmed MF. Oral health status of 12-year-old school children in Khartoum state, the Sudan; a school-based survey. BMC Oral Health. 2009;9(1):15.

23. Andegiorgish AK, Weldemariam BW, Kifle MM, Mebrahtu FG, Zewde HK, Tewelde MG, et al. Prevalence of dental caries and associated factors among 12 years old students in Eritrea. BMC Oral Health. 2017;17(1):169.

24. Alami A, Nedjat S, Majdzadeh R, Rahimi Foroushani A, Hoseini SJ, Malekafzali H. Factors influencing women's willingness to volunteer in the healthcare system: evidence from the Islamic Republic of Iran. Eastern Mediterranean health journal = La revue de sante de la Mediterranee orientale $=$ alMajallah al-sihhiyah li-sharq al-mutawassit. 2013;19(4):348-55.

25. Sajadi F-S, Mosharafian S, Torabi M, Hajmohamadi S. Evaluation of DMFT index and Significant Caries Index in 12-year-old students in Sirjan, Kerman. Journal of Isfahan Dental School. 2014;10(4):290-8.

26. Asdagh S, Nuroloyuni S, Amani F, SadeghiMazidi T. Dental Caries Prevalence among 6-12 Years Old School Children in Ardabil City, 2012. Journal of Ardabil University of Medical Sciences. 2015;15(1):39-45.

27. Al-Samadani K, Ahmad M, Bakeer H, Elanbya MO. Oral health knowledge and practice among 9-12year-old schoolchildren in the region of Madinah, Saudi Arabia, and its impact on the prevalence of dental caries. European Journal of General Dentistry. 2017;6(1):54-8.

28. Kim H-N, Han D-H, Jun E-J, Kim S-Y, Jeong S-H, Kim J-B. The decline in dental caries among Korean children aged 8 and 12 years from 2000 to 2012 focusing SiC Index and DMFT. BMC Oral Health. 2016;16(1):38.

29. Huew R, Waterhouse PJ, Moynihan PJ, Maguire A. Prevalence and severity of dental caries in Libyan schoolchildren. Int Dent J. 2011;61(4):217-23.

30. Yin W, Yang Y-M, Chen H, Li X, Wang Z, Cheng L, et al. Oral health status in Sichuan Province: findings from the oral health survey of Sichuan, 2015-2016. International Journal Of Oral Science. 2017;9:10.

31. Hazavehei SMM, Shirahmadi S, Taheri M, Noghan N, Rezaei N. Promoting Oral Health in 6-12 YearOld Students: A Systematic Review. Journal of Education and Community Health. 2015;1(4):66-84.

32. Yuan $C$, Wang $X Z$, Sun $X Y$, Wang $X$, Feng XP, Tai BJ, et al. Oral Health Status of 12-year-olds from Regions with and without Coverage of the National Oral Health Comprehensive Intervention Program 
for Children in China. The Chinese journal of dental research : the official journal of the Scientific Section of the Chinese Stomatological Association (CSA). 2018;21(4):299-306.

33. Zhang S, Xu B, Liu J, Lo ECM, Chu C-H. Dental and periodontal status of 12-year-old Dai school children in Yunnan Province, China: a cross-sectional study. BMC Oral Health. 2015;15(1):117.

34. Yousofi M, Behrouzpour K, Kazemi S, Afroughi S. Dental Caries and Related Factors among 7-12 Year-old School Children in Yasuj, Iran, in 2014. Armaghane danesh. 2015;20(9):836-47.

35. Toomarian L, Souri S, Farhadi H. Epidemiological evaluation of DMFT index in 12 - year - old students of Qom city in 1383. Journal of Dental School Shahid Beheshti University of Medical Sciences. 2005;23(3):467-74.

36. Giacaman RA, Bustos IP, Bazan P, Marino RJ. Oral health disparities among adolescents from urban and rural communities of central Chile. Rural and remote health. 2018;18(2):4312.

37. Rahimian Emam S, Haghgoo R, Amirabadi F, R JH. Comparison of DMFT index in retarded 8-12 yearold students with healthy subjects in Zahedan from 2013 to 2014. Daneshvar. 2015;22(116):57-64.

38. Faezi M, Farhadi S, NikKerdar H. Correlation between dmft, diet and social factors in primary school children of Tehran-Iran in 2009-2010. Journal of Mashhad Dental School. 2012;36(2):141-8.

39. A Eskandaryzedeh, FS Sajadi, M Torabi, Z Amini , M Sharifi , etal a. Caries Free Prevalence among 6, 12 \&amp;amp;amp; 15-Year Old School Children in Kerman during 2000-2005. Journal of Health and Development. 2015;4(1):42-0.

40. Quan JK, Wang XZ, Sun XY, Yuan C, Liu XN, Wang X, et al. Permanent Teeth Caries Status of 12- to 15-year-olds in China: Findings from the 4th National Oral Health Survey. The Chinese journal of dental research : the official journal of the Scientific Section of the Chinese Stomatological Association (CSA). 2018;21(3):181-93.

41. Oulis CJ, Tsinidou K, Vadiakas G, Mamai-Homata E, Polychronopoulou A, Athanasouli T. Caries prevalence of 5, 12 and 15-year-old Greek children: a national pathfinder survey. Community dental health. 2012;29(1):29-32.

42. rezaei z, Mansouri B, Pashaei T, Ali-Hossaeni M, Habibi Y, GHaribi F, et al. Survey of dmft status in elementary school students in Sanandaj City in 2014. Zanko Journal of Medical Sciences. 2015;15(47):30-7.

43. shariat e, mohammad nejad e, begjani j, abootalebi g. Evaluation of Oral Health in Primary School Children in Saveh,Iran. Journal of Research Development in Nursing and Midwifery. 2011;8(1):74-80.

44. Wigen TI, Wang NJ. Caries and background factors in Norwegian and immigrant 5-year-old children. Community Dent Oral Epidemiol. 2010;38(1):19-28.

45. Folayan MO, Owotade F, Oziegbe EO, Fadeyibi R. Effect of birth rank on the caries experience of children from a suburban population in Nigeria. Journal of Dentistry and Oral Hygiene. 2010;2(3):2730.

46. Folayan M, Kolawole K, Oziegbe E, Oyedele T, Agbaje H, Onjejaka N, et al. Association between family structure and oral health of children with mixed dentition in suburban Nigeria. Journal of Indian Society of Pedodontics and Preventive Dentistry. 2017;35(2):134-42. 
47. Basha S, Swamy HS. Dental caries experience, tooth surface distribution and associated factors in 6and 13-year- old school children from Davangere, India. Journal of clinical and experimental dentistry. 2012;4(4):e210-6.

\section{Tables}

Table 1- DMFT assessment in students of 12 year-old

\begin{tabular}{|c|c|c|c|c|c|}
\hline \multicolumn{3}{|c|}{ Variables } & \multirow{2}{*}{$\begin{array}{c}\text { Mean } \\
\text { Rank } \\
543.64\end{array}$} & \multirow{2}{*}{$\begin{array}{l}\text { Mean } \pm \text { SD } \\
1.47 \pm 0.98\end{array}$} & \multirow{2}{*}{$\begin{array}{c}\text { P- } \\
\text { Value } \\
<0.001\end{array}$} \\
\hline \multirow{2}{*}{ Gender* } & Boy & $601(47)$ & & & \\
\hline & Girl & $679(53)$ & 726.23 & $1.98 \pm 1.91$ & \\
\hline \multirow{2}{*}{ Place of residence ${ }^{*}$} & Town & $952(74.6)$ & 652.39 & $1.85 \pm 1.54$ & \multirow[t]{2}{*}{0.015} \\
\hline & Village & $324(25.4)$ & 597.68 & $1.71 \pm 1.29$ & \\
\hline \multirow{2}{*}{ Insurance* } & Yes & 1218(95.2) & 640.77 & $1.48 \pm 1.82$ & \multirow[t]{2}{*}{0.902} \\
\hline & No & $62(4.8)$ & 635.18 & $1.37 \pm 1.62$ & \\
\hline \multirow{4}{*}{$\begin{array}{c}\text { Father's } \\
\text { occupation\# }\end{array}$} & Unemployed & $15(1.2)$ & 638.77 & $1.27 \pm 1.38$ & \multirow[t]{4}{*}{0.954} \\
\hline & Retired & $53(4.2)$ & 645.45 & $1.57 \pm 1.94$ & \\
\hline & $\begin{array}{l}\text { Self-employed and } \\
\text { worker }\end{array}$ & $881(70)$ & 632.48 & $1.47 \pm 1.81$ & \\
\hline & Employee & $311(24.6)$ & 621.95 & $1.44 \pm 1.83$ & \\
\hline \multirow{3}{*}{$\begin{array}{c}\text { Mother's } \\
\text { occupation\# }\end{array}$} & Homemaker & $1031(81.1)$ & 631.03 & $1.44 \pm 1.78$ & \multirow[t]{3}{*}{0.341} \\
\hline & Employee & $171(13.4)$ & 642.84 & $1.56 \pm 1.97$ & \\
\hline & Other & $69(5.5)$ & 693.28 & $1.72 \pm 1.81$ & \\
\hline \multirow[t]{3}{*}{$\begin{array}{l}\text { Father's } \\
\text { education }{ }^{\#}\end{array}$} & $\begin{array}{l}\text { Primary school } \\
\text { education }\end{array}$ & $301(24)$ & 665.38 & $1.30 \pm 1.75$ & \multirow[t]{3}{*}{0.055} \\
\hline & $\begin{array}{l}\text { Middle and high } \\
\text { school education }\end{array}$ & $651(51.8)$ & 650.08 & $1.57 \pm 1.84$ & \\
\hline & University education & $304(24.2)$ & 614.54 & $1.43 \pm 1.86$ & \\
\hline \multirow[t]{3}{*}{$\begin{array}{l}\text { Mother's } \\
\text { education" }\end{array}$} & $\begin{array}{l}\text { Primary school } \\
\text { education }\end{array}$ & $370(29.3)$ & 593.06 & $1.28 \pm 1.72$ & \multirow[t]{3}{*}{0.035} \\
\hline & $\begin{array}{l}\text { Middle and high } \\
\text { school education }\end{array}$ & $635(50.3)$ & 646.15 & $1.53 \pm 1.80$ & \\
\hline & University education & $258(20.4)$ & 653.02 & $1.63 \pm 1.98$ & \\
\hline \multirow{2}{*}{$\begin{array}{l}\text { Use fluoridated } \\
\text { Mouthwash }^{*}\end{array}$} & Yes & $201(16.4)$ & 639.35 & $1.65 \pm 1.99$ & \multirow[t]{2}{*}{0.187} \\
\hline & No & $1020(83.6)$ & 605.41 & $1.41 \pm 1.75$ & \\
\hline \multirow[t]{2}{*}{ Use dental floss* } & Yes & $308(25.2)$ & 629.35 & $1.54 \pm 1.81$ & \multirow[t]{2}{*}{0.292} \\
\hline & No & $915(74.8)$ & 606.16 & $1.42 \pm 1.79$ & \\
\hline \multirow{2}{*}{$\begin{array}{l}\text { Brush teeth } \\
{ }^{*} \text { regularly }\end{array}$} & Yes & $1107(88.5)$ & 627.27 & $1.49 \pm 1.83$ & \multirow[t]{2}{*}{0.611} \\
\hline & No & $143(11.5)$ & 611.82 & $1.36 \pm 1.63$ & \\
\hline \multirow[t]{2}{*}{ Birth rank* } & $1-3$ & $1152(90.5)$ & 629.76 & $1.44 \pm 1.79$ & \multirow[t]{2}{*}{0.032} \\
\hline & 4 or more & $120(9.5)$ & 701.19 & $1.85 \pm 2.05$ & \\
\hline
\end{tabular}


Page 12/14 
Table 2- Relationship between DMFT of 12 year-old students and selected variables in the Univariate and Multivariate logistic regression models

\begin{tabular}{|c|c|c|c|c|c|c|c|c|}
\hline \multicolumn{5}{|c|}{ Univariate } & \multicolumn{4}{|c|}{ Multivariate } \\
\hline Variables & $\begin{array}{l}\text { Regression } \\
\text { coefficient }\end{array}$ & $\begin{array}{l}\text { Odds } \\
\text { ratio }\end{array}$ & $\begin{array}{l}95 \% \\
\text { C.I. }\end{array}$ & $\begin{array}{c}\text { P- } \\
\text { Value }\end{array}$ & $\begin{array}{l}\text { Regression } \\
\text { coefficient }\end{array}$ & $\begin{array}{l}\text { Odds } \\
\text { ratio }\end{array}$ & $\begin{array}{l}95 \% \\
\text { C.I. }\end{array}$ & $\begin{array}{c}\text { P- } \\
\text { Value }\end{array}$ \\
\hline \multicolumn{9}{|l|}{$\begin{array}{l}\text { SEX } \\
\text { Boy }^{\mathrm{a}}\end{array}$} \\
\hline Girl & 0.94 & 2.58 & $\begin{array}{l}2.06- \\
3.23\end{array}$ & $<0.001$ & 0.99 & 2.69 & $\begin{array}{l}2.13- \\
3.39\end{array}$ & $<0.001$ \\
\hline Father's age & 0.001 & 1.00 & $\begin{array}{l}0.98- \\
1.01\end{array}$ & 0.949 & --- & --- & --- & --- \\
\hline Mother's age & 0.006 & 1.00 & $\begin{array}{l}0.98^{-} \\
1.02\end{array}$ & 0.555 & ---- & ---- & ---- & $-\overline{---}$ \\
\hline \multicolumn{9}{|l|}{$\begin{array}{c}\text { Birth rank } \\
1-3^{a}\end{array}$} \\
\hline 4 or more & 0.37 & 1.45 & $\begin{array}{l}0.98- \\
2.13\end{array}$ & 0.060 & 0.66 & 1.93 & $\begin{array}{l}1.27- \\
2.94\end{array}$ & 0.002 \\
\hline \multicolumn{9}{|l|}{ Insurance } \\
\hline $\begin{array}{l}\mathrm{No}^{\mathrm{a}} \\
\text { Yes }\end{array}$ & -0.09 & 0.90 & $\begin{array}{l}0.54- \\
1.52\end{array}$ & 0.718 & --- & --- & --- & --- \\
\hline $\begin{array}{l}\text { Father's occupation } \\
\text { Unemployed }\end{array}$ & & & & & --- & --- & --- & --- \\
\hline Retired & -0.51 & 0.59 & $\begin{array}{l}0.20- \\
1.76\end{array}$ & 0.352 & ---- & --- & ---- & ---- \\
\hline $\begin{array}{l}\text { Self- } \\
\text { workerand employed }\end{array}$ & -0.42 & 0.65 & $\begin{array}{l}0.19- \\
2.17\end{array}$ & 0.486 & --- & --- & --- & --- \\
\hline Employee & -0.62 & 0.53 & $\begin{array}{l}0.17- \\
1.60\end{array}$ & 0.266 & ---- & --- & --- & ---- \\
\hline $\begin{array}{l}\text { Mother's occupation } \\
\text { Homemaker }^{\mathrm{a}}\end{array}$ & & & & & --- & --- & --- & --- \\
\hline Employee & 0.02 & 1.02 & $\begin{array}{l}0.73- \\
1.41\end{array}$ & 0.893 & ---- & --- & ---- & ---- \\
\hline Other & 0.28 & 1.33 & $\begin{array}{l}0.81- \\
2.19\end{array}$ & 0.257 & ---- & --- & --- & ---- \\
\hline \multicolumn{9}{|l|}{$\begin{array}{c}\text { Place of residence } \\
\text { Rural }^{\mathrm{a}}\end{array}$} \\
\hline Urban & 0.36 & 1.44 & $\begin{array}{l}1.12- \\
1.86\end{array}$ & 0.004 & 0.39 & 1.48 & $\begin{array}{l}1.12- \\
1.96\end{array}$ & 0.005 \\
\hline \multicolumn{9}{|l|}{$\begin{array}{l}\text { Father's education } \\
\text { Primary } \\
\text { school education }^{\mathrm{a}}\end{array}$} \\
\hline $\begin{array}{l}\text { Middle and high } \\
\text { school education }\end{array}$ & 0.24 & 1.27 & $\begin{array}{l}0.96- \\
1.67\end{array}$ & 0.084 & -0.02 & 0.98 & $\begin{array}{l}0.71- \\
1.35\end{array}$ & 0.901 \\
\hline University education & 0.02 & 1.02 & $\begin{array}{l}0.74- \\
1.40\end{array}$ & 0.905 & -0.41 & 0.66 & $\begin{array}{l}0.43- \\
0.99\end{array}$ & 0.049 \\
\hline \multicolumn{9}{|l|}{$\begin{array}{l}\text { Mother's education } \\
\text { Primary } \\
\text { school education }^{\mathrm{a}}\end{array}$} \\
\hline $\begin{array}{l}\text { Middle and high } \\
\text { school education }\end{array}$ & 0.26 & 1.29 & $\begin{array}{l}1.00- \\
1.67\end{array}$ & 0.047 & 0.40 & 1.49 & $\begin{array}{l}1.09- \\
2.03\end{array}$ & 0.011 \\
\hline & & & & 0.110 & 0.49 & & & \\
\hline
\end{tabular}




\begin{tabular}{|c|c|c|c|c|c|c|c|c|}
\hline University education & 0.26 & 1.29 & $\begin{array}{c}0.94- \\
1.78\end{array}$ & & & 1.63 & $\begin{array}{l}1.08- \\
2.47\end{array}$ & 0.020 \\
\hline $\begin{array}{c}\text { Brush teeth regularly } \\
\text { Yes }^{\mathrm{a}}\end{array}$ & & & & \multirow[b]{2}{*}{0.618} & \multirow{2}{*}{--- } & ---- & ---- & ---- \\
\hline No & -0.08 & 0.91 & $\begin{array}{l}0.64- \\
1.29\end{array}$ & & & --- & ---- & --- \\
\hline \multicolumn{9}{|l|}{$\begin{array}{c}\text { Use } \\
\text { Mouthwash fluoridated }\end{array}$} \\
\hline $\begin{array}{c}\text { Yes }^{\mathrm{a}} \\
\text { No }\end{array}$ & -0.14 & 0.86 & $\begin{array}{c}0.64- \\
1.17 \\
\end{array}$ & 0.366 & --- & --- & --- & --- \\
\hline $\begin{array}{l}\text { Use dental floss } \\
\text { Yes }^{\mathrm{a}}\end{array}$ & & & & & --- & ---- & ---- & ---- \\
\hline No & -0.10 & 0.90 & $\begin{array}{l}0.69- \\
1.17\end{array}$ & 0.445 & --- & ---- & ---- & ---- \\
\hline${ }^{\mathrm{a}}$ Reference category & & & & & & & & \\
\hline
\end{tabular}

